\title{
Appraisal of Quality of Groundwater in Selected Sites in the Villages of Veeraghattam Mandal in Srikakulam District, Andhra Pradesh, India
}

\author{
Nadikatla Santhosh Kumar ${ }^{1 *}$, Mushini Venkata SubbaRao', Mudumba Phani Surya Murali \\ Krishna ${ }^{2}$
}

${ }^{1}$ Department of Chemistry, G M R Institute of Technology (Affiliated to JNTUK, Kakinada), Rajam, Srikakulam District, Andhra Pradesh, India. ${ }^{2}$ Department of Chemistry, Andhra Polytechnic, Kakinada, Andhra Pradesh, India.

Received: 06/01/2020 Accepted: 13/04/2020_ Published: 20/09/2020

\begin{abstract}
The Potability of groundwater in selected location sites in the villages of Veeraghattam (VGT) Mandal of Srikakulam district, Andhra Pradesh has been investigated and obtained Water Quality Index (WQI) results are presented in this paper. Several Physico-chemical parameters like pH, Electrical Conductivity (EC), turbidity, Total Dissolved Solids (TDS), Total Hardness, calcium, magnesium, fluoride, chloride, dissolved oxygen, total alkalinity, and nitrite were experimentally determined from the samples and also to compute WQI. The results of WQI computation infer that the quality of groundwater in selected site locations in rural communities in Veeraghattam Mandal is rated as "good" for human consumption. Correlation between various parameters has also been computed, and the results are presented.
\end{abstract}

Keywords: Physico-chemical parameters, Veeraghattam (VGT), WQI, Srikakulam, Correlation matrix

\section{Introduction}

One of the utmost necessary things for living beings in the world is water. We always think water should be available sufficiently and freely as a gift of nature. Hygienic, harmless and suitable freshwater is vital to the survival of human beings. The assertion of drinking-water safety is a foundation for the prevention and control of waterborne diseases. The drinking water quality affects the health of human beings [1] due to the presence of various unwanted chemical constituents and also many diseases associated with these phenomena either directly or indirectly depend on the quality of the drinking water. In the majority of the places in India [2] as well as in other countries of the world, people mainly depend on groundwater for their needs [3-5]. According to Li P et al.[6], the main reasons are the increased population, various human activities such as industrialization, dumping of industrial waste and the increased use of fertilizers; the pollution of freshwater resources occurs due to wastewater disposal in the most areas. Access to potable water is one of the Millennial Development Goals (MDGs) in all emerging nations of the globe. This goal is nonetheless to be realised as a result of associate degree calculable two billion individuals lack access to potable water globally [7].

Groundwater is safer than surface-water, and at present, the quality of groundwater differs from one place to another place and this could thus affect its suitableness for potability [8]. An impure groundwater resource might initiate waterborne diseases, inflammatory disease, cholera, typhoid [9] and protozoan infection [10]. However, once groundwater is sufficiently safeguarded and well managed, it might be an honest supply of potable water. Groundwater is deemed as one of the perfect forms of water accessible in Nature to serve the necessities of rural and urban people. The major part of the Indian populace relies on freshwater supplies from lakes, borewells, and open wells, natural springs, and so on. Besides, the majority of the people utilise groundwater continuously for all their domestic activities and irrigation in India [11]. In some parts of Asian countries, the rural population has to travel half a mile to access to drinking water since they lack the necessary infrastructures for the water purification. The principal threat to groundwater quality embodied household and industrial wastes in addition to the use of agricultural composts and pesticides [12]. These pollutants may cause contamination by penetrating aquifers through the stream; for example, Nitrate is hazardous to infants; it affects a disease called 'methemoglobinemia' [13].

Characteristics of Groundwater in Southern India are strongly structured over bedrock geology and local weather, but additionally may keep impacted in components through pollution, especially by agricultural and industrial sources, etc. Most probably, an effect of contamination is due to the extended elements of Total Dissolved Solids (TDS) [14]. Groundwater is utilised in residential as well as in industrial water supply systems throughout the world. As a result, the quick development of the populace and the quick progress of industrialisation, for the past few years, the requirement for freshwater has been increased enormously. Fast urbanization, particularly in emerging nations like India has pretentious the provision of the prominence of the worth of groundwater, because of its overexploitation and ill-advised waste transfer, particularly in the zones of urban [15]. As per WHO (2012), around $80 \%$ of the considerable number of ailments peoples are affected by water [16]. When the water in the underground is

*Corresponding Author: Nadikatla Santhosh Kumar, Department of Chemistry, G M R Institute of Technology (Affiliated to JNTUK, Kakinada), Rajam, Srikakulam District, Andhra Pradesh, India. E-mail: santoshkumar.n@gmrit.edu.in 
defiled, the quality cannot be brought back by preventing the contaminations from the resource. In this line, monitoring is to be developed habitually often to observe the water quality and plan to develop techniques to safeguard it.

WQI is the foremost efficient method to convey data on the quality of water to the populaces as well as policymakers. The Quality Index of Water is characterized as a grading mirroring the complex impact of various constituents present in the groundwater quality. The Quality Index for water is to find out from the perspective of the appropriateness of water for individual utilization [17]-[18]. The research work aims to examine the appropriateness of groundwater for suitability to human beings in the selected region for potable purposes because of processed WQI values. Under the study area, the people mainly utilizes a huge amount of groundwater for their agricultural activities by farmers continuously in addition to the potable purpose. Additionally, scarcity of water, intensive agriculture has created a huge demand for the groundwater resources in the low and medium rainfall received regions per year in the villages of Veeraghattam Mandal. The villages in this Mandal belong to coastal area which is nearer to the Bay of Bengal. Within the coastal areas, an intrusion of brine is also polluting the groundwater resources [19]. Given all the factors considered into account, the present study on this topic selected for selected locations in Veeraghattam Mandal to assess the groundwater quality.

\section{Study area}

Veeraghattam (VGT), one of the rural Mandal(Figure 1) in Srikakulam District of Andhra Pradesh State belongs to northern coastal of A.P in India and is located $59 \mathrm{KM}$ from Srikakulam with Latitude $18^{\circ} 41^{\prime} 11^{\prime \prime} \mathrm{E}$ and longitude $83^{\circ} 36^{\prime}$ $38 \mathrm{~N}$. Majority of the people in this Mandal belongs to their occupation is agriculture and small scale business.

\section{Materials and methodology}

The water samples (40) from selected locations are collected, and the detailed is given the Table 1 for the period of pre-monsoon and post-monsoon seasons of December 2013 (S1), June 2014 (S2), December 2014 (S3), June 2015 (S4), December 2015 (S5), June 2016 (S6). Collected samples are from bore-wells only after sufficient pumping (purging) to ensure that the sample represents the groundwater source. The sample containers are thoroughly cleaned before the collection and rinse the sample container two or three times with the sample before it is filled. Precautionary methods of collection and preservation of the sample will be taken care of. As deterioration affects the results, samples requiring preservation are preserved as per the drinking water norms IS: 10500 (2012) of the Bureau of Indian Standards (BIS). All samples are analyses for various physicochemical constituents' estimation are done based on available established standard methods [20].

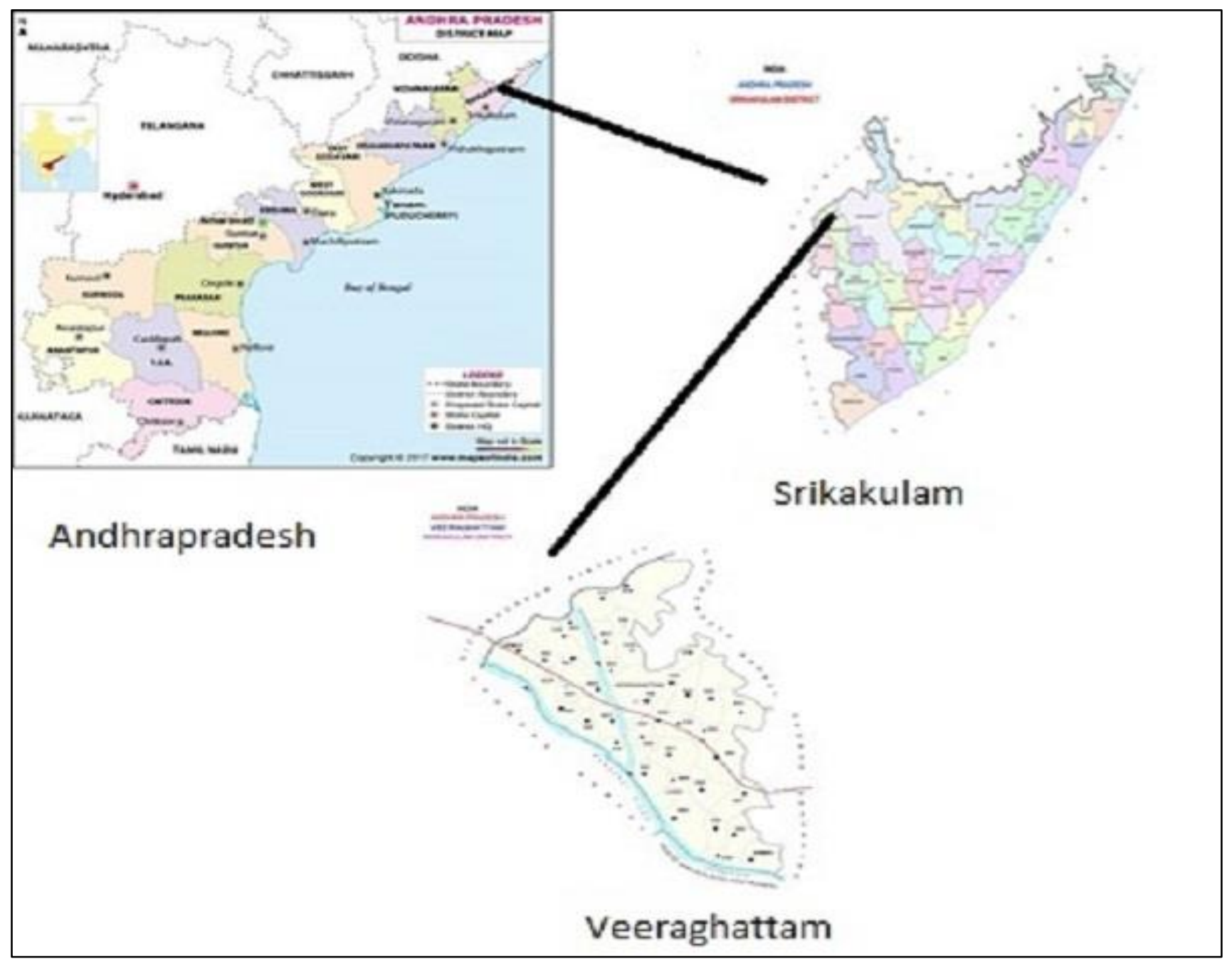

Figure 1: study area of Veeraghattam Mandal 
All the used Chemicals are of Analytical Reagent Grade and working solutions are freshly made with triple distilled water. The electrical conductance and $\mathrm{pH}$ of the collected water samples were assessed on the spot by using ELICO PE138 water quality analyzer. Chloride ion concentration present in the water sample was determined by Argentometric titration using $\mathrm{K}_{2} \mathrm{CrO}_{4}$ as an indicator. The method used for the analysis of calcium and total hardness was EDTA Titration. Magnesium was estimated as the difference between hardness and calcium with the help of a formula. Turbidity was measured by using the Nephelometer (Model 132, Systronics). The chemical constituent total alkalinity was measured by acid titration. Fluoride ion concentration was measured by fluoride sensitive electrode, Nitrite ion $\left(\mathrm{NO}_{2}{ }^{-}\right)$was determined by UV-Visible Double beam Spectrophotometer (Model AU- 2701, Systronics).

\section{Results and discussion \\ $4.1 \mathrm{pH}$}

$\mathrm{pH}$ is a significant factor for water. For successful purification with chlorine, the $\mathrm{pH}$ ought to ideally be under eight, in any case, bring down $\mathrm{pH}$ of water $(<7)$ will probably be destructive. The inability to limit consumption can bring about the defilement of drinking water and an antagonistic impact on its taste and appearance [21]. The $\mathrm{pH}$ fluctuates between slightly acidic to slightly alkaline in the selected sites of this Mandal. The hydrogen ion concentration ranging in selected sites in Veeraghattam Mandal amidst 6.56-8.06 with arithmetic mean value of 6.56 in before monsoon, and 6.61-8.1 with a mean value of 6.61 during the post-monsoon season. Which is within the limit of BIS [22] and WHO [16] guidelines (6.5-8.5) for drinking water (Figure 2).

\subsection{Electrical Conductivity (EC)}

In the collected water samples in this study area, the EC is ranging between 316 to 3541 micromhos $/ \mathrm{cm}$ having a mean value of 1261.63 micromhos/cm before monsoon season. In the post-monsoon, in the samples, the conductivity was observed a ranging between 302 to 3532 micromhos/cm and having a mean value of 1265 micromhos $/ \mathrm{cm}$ the entire data was pictorially represented in Figure 3. Based on the obtained results, the EC values were very distinct before and after monsoon seasons, according to WHO [16] the EC in potable water would be the range of $500 \mathrm{mg} / \mathrm{L}$ as good. The obtained results reveal that the conductivity in the 37 samples $(92.5 \%)$ out of 40 in both the seasons are not within the allowable limit except V23, V29, and V35 samples. The EC of water is a direct function of its TDS [23]. Therefore, it is key to signifying the presence of soluble salts in the groundwater.

\subsection{Turbidity}

Due to the existence of suspended solids ad slit, the groundwater acquires turbidity. The turbid nature of groundwater is caused by the presence of suspended solids and silt. As per literature reports a relationship has established between gastrointestinal infections with turbidity [21]. In this study the observed results in the selected area of water samples having the range of $0.14-6.04 \mathrm{NTU}$ in the before monsoon season and also identified as 1.56 Nephelo Turbidity Units as mean value. During post monsoon, the turbidity values are observed closely the same as pre monsoon and having a mean value of $1.60 \mathrm{NTU}$ with a range of 0.16 to $6.22 \mathrm{NTU}$. The entire obtained data were shown in Figure 4 in pictorial. Based on the results, the observation was that the turbidity was slightly higher in the season of post-monsoon than that of pre-monsoon. According to BIS [22] in the potable water, the turbidity should be required as good the limit of $1.0 \mathrm{NTU}$ and in alternate cases, if such type of water is not available, the allowable limit is up to 5.0 NTU. In the present analysis, $97.5 \%$ of the Veeraghattam Madal selected samples were well within the allowable limit, except for the V1 sample in Veeraghattam Mandal.

Table 1: List of sample sites of villages in Veeraghattam Mandal

\begin{tabular}{llll}
\hline \multirow{2}{*}{ Sample } & & \multicolumn{2}{c}{ Veeraghattam Mandal } \\
\cline { 2 - 4 } & Location/Villages & Sample & Location/Villages \\
\hline $\mathrm{V}_{1}$ & Veeraghattam & $\mathrm{V}_{21}$ & Santha Narsipuram \\
$\mathrm{V}_{2}$ & Veeraghattam & $\mathrm{V}_{22}$ & Mahadevavalasa \\
$\mathrm{V}_{3}$ & Veeraghattam & $\mathrm{V}_{23}$ & Dasamanthuram \\
$\mathrm{V}_{4}$ & Veeraghattam & $\mathrm{V}_{24}$ & Chalivendri \\
$\mathrm{V}_{5}$ & Veeraghattam & $\mathrm{V}_{25}$ & Buruga \\
$\mathrm{V}_{6}$ & Veeraghattam & $\mathrm{V}_{26}$ & S.Gopalapuram \\
$\mathrm{V}_{7}$ & Talavaram & $\mathrm{V}_{27}$ & Kottugummada \\
$\mathrm{V}_{8}$ & Panasa Nandivada & $\mathrm{V}_{28}$ & Kottugummada \\
$\mathrm{V}_{9}$ & Neelanagaram & $\mathrm{V}_{29}$ & Gadagamma \\
$\mathrm{V}_{10}$ & Tettangi & $\mathrm{V}_{30}$ & Tudi \\
$\mathrm{V}_{11}$ & Bitiwada & $\mathrm{V}_{31}$ & Tudi \\
$\mathrm{V}_{12}$ & Adaru & $\mathrm{V}_{32}$ & Chdimi \\
$\mathrm{V}_{13}$ & Bodlapadu & $\mathrm{V}_{33}$ & Palametta \\
$\mathrm{V}_{14}$ & Regulapadu & $\mathrm{V}_{34}$ & Kummidi \\
$\mathrm{V}_{15}$ & Kella & $\mathrm{V}_{35}$ & Gangampeta \\
$\mathrm{V}_{16}$ & Nadimikella & $\mathrm{V}_{36}$ & Rajapuram \\
$\mathrm{V}_{17}$ & Kambara & $\mathrm{V}_{37}$ & Kattula Kaviti \\
$\mathrm{V}_{18}$ & Kambaravalasa & $\mathrm{V}_{38}$ & Hussenpuram \\
$\mathrm{V}_{19}$ & Vikrampuram & $\mathrm{V}_{39}$ & Venkampeta \\
$\mathrm{V}_{20}$ & Nadukuru & $\mathrm{V}_{40}$ & Achipuvalasa \\
\hline
\end{tabular}




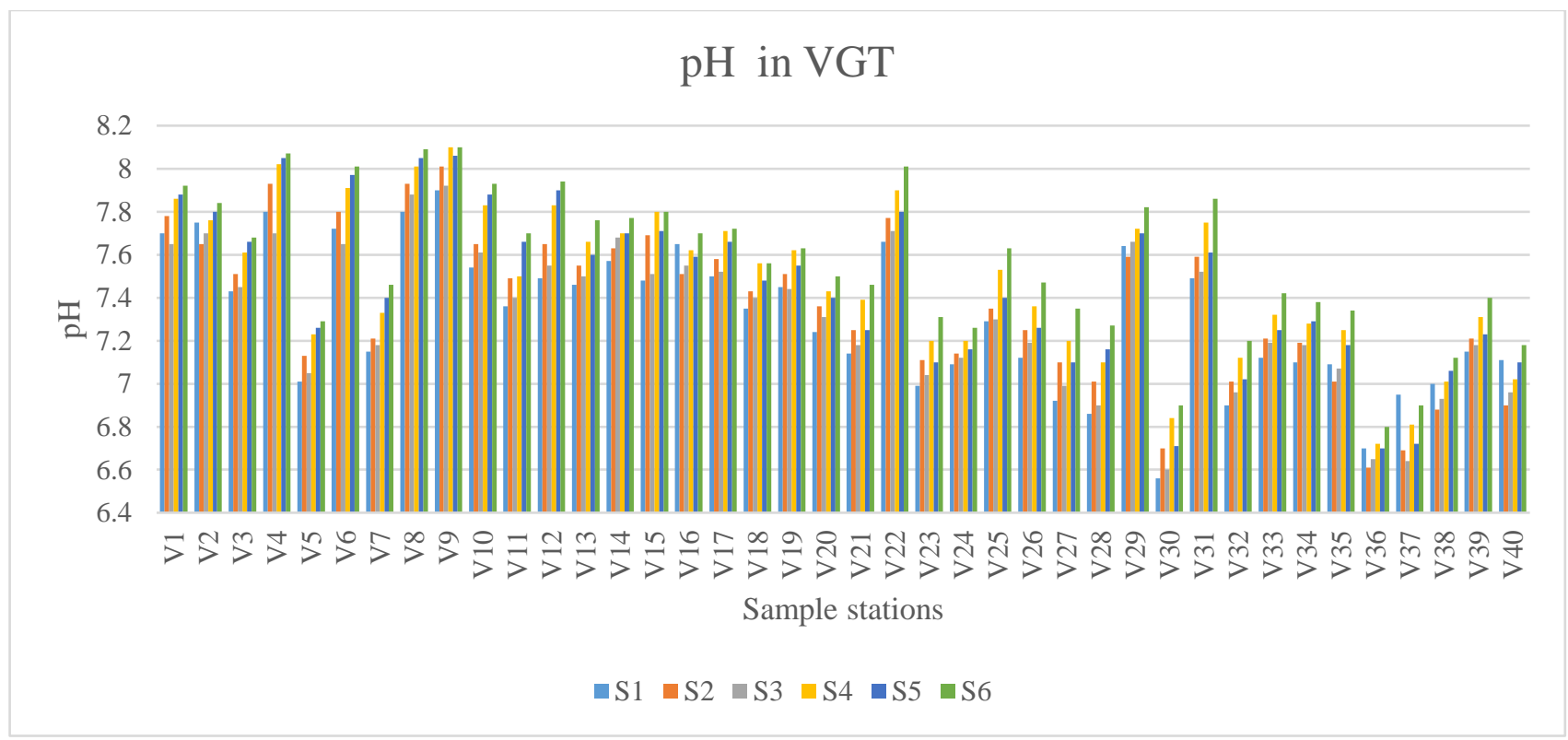

Figure 2: Seasonal variation of $\mathrm{pH}$ in selected sample locations in Veeraghattam Mandal

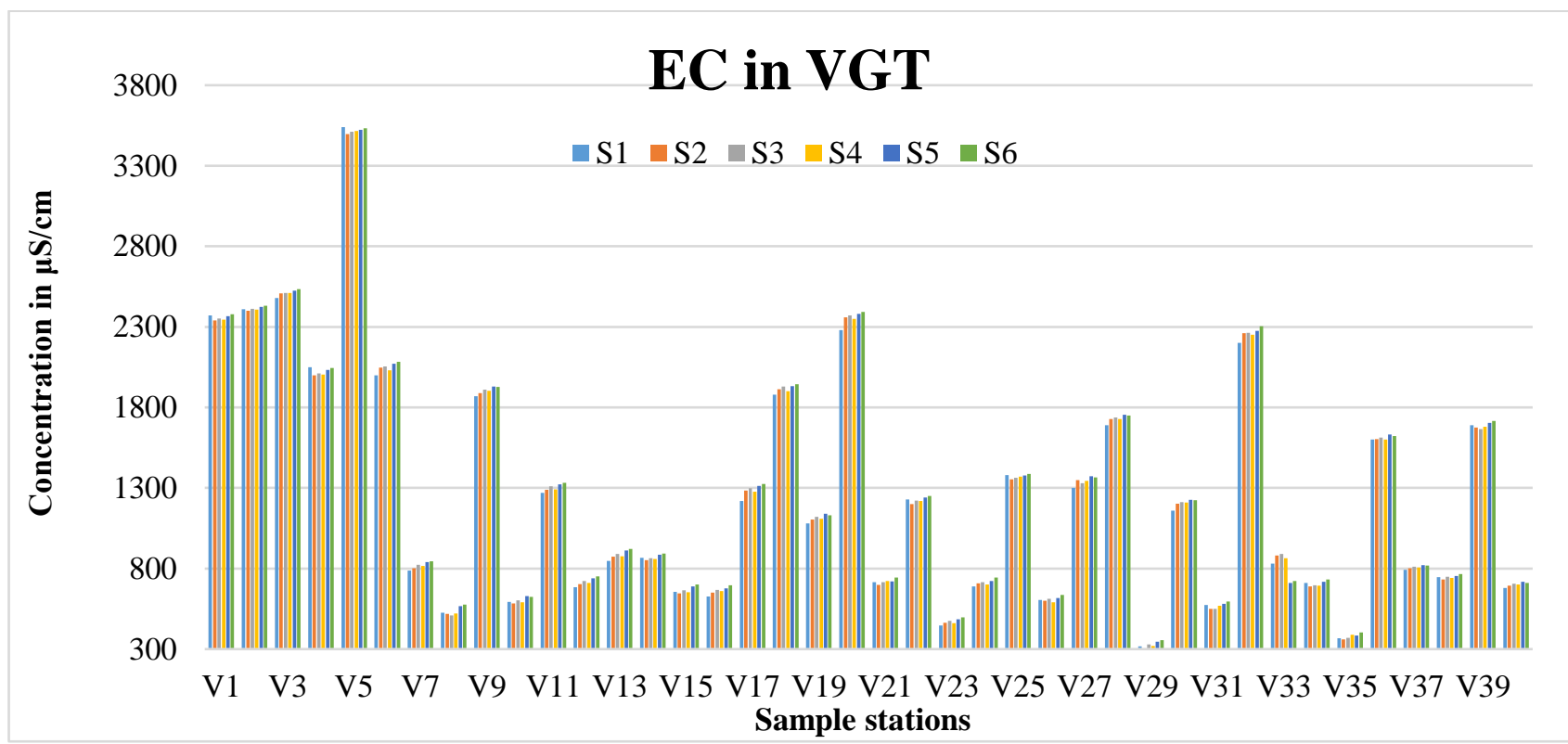

Figure 3: Seasonal variation of EC in selected sample locations in Veeraghattam Mandal

\subsection{Total dissolved solids (TDS)}

Total Dissolved Solids are placed a vital role in the drinking water and these are leading to affect the taste of water. The greatest permissible limit allowable utmost of TDS for potability tenacity was $500 \mathrm{mg} / \mathrm{l}$ and probably in the alternate source desirable limit was accepted upto $1500 \mathrm{mg} / \mathrm{l}$ by WHO if satisfactory water was not available [16] in that area. In this research study the obtained dissolved solids as a total in the water samples are observed between 144-2921 mg/L having $864.18 \mathrm{mg} / \mathrm{L}$ of mean value in the before monsoon and in between $184-2916 \mathrm{mg} / \mathrm{L}$ during post-monsoons with 873.35 $\mathrm{mg} / \mathrm{L}$ as mean value respectively. The results revealed that 25 samples $(31.6 \%)$ of pre-monsoon and 23 samples of $(29.1 \%)$ post-monsoon, the dissolved solids content are identified more than $500 \mathrm{mg} / \mathrm{L}$. The TDS variation in different seasons are pictorially presented in Figure 5. The possible cause may be in the samples shows high solids due to the presence of laxative or constipation effects.

\subsection{Total hardness $(\mathrm{TH})$}

The amount of hardness of the groundwater is owing to the presence of $\mathrm{Ca}$, and $\mathrm{Mg}$ ions holding minerals are geologically existing in the freshwater sources. The water is contaminated due to the cause of the presence of the $\mathrm{CO}_{3}{ }^{2-}$ and $\mathrm{HCO}_{3}{ }^{-}$of $\mathrm{Ca}$ and $\mathrm{Mg}$, limestone $\left(\mathrm{CaCO}_{3}\right)$ and dolomite, and in water hardness contribution is owning to the $\mathrm{Ca}$ and $\mathrm{Mg}$ salts. In this research study, the obtained results indicate that the water samples having the hardness in-between 148 to $1826 \mathrm{mg} / \mathrm{L}$ in the post monsoon with an average value of $447.53 \mathrm{mg} / \mathrm{L}$. The same trend was observed in the post monsoon season with hardness values in between 154 to $1813 \mathrm{mg} / \mathrm{L}$ in the water samples and consisting of the mean value $447.88 \mathrm{mg} / \mathrm{L}$, Finally the results revealed that the water samples having above the mean value of the standards as per BIS (300 mg/L) [22]. 


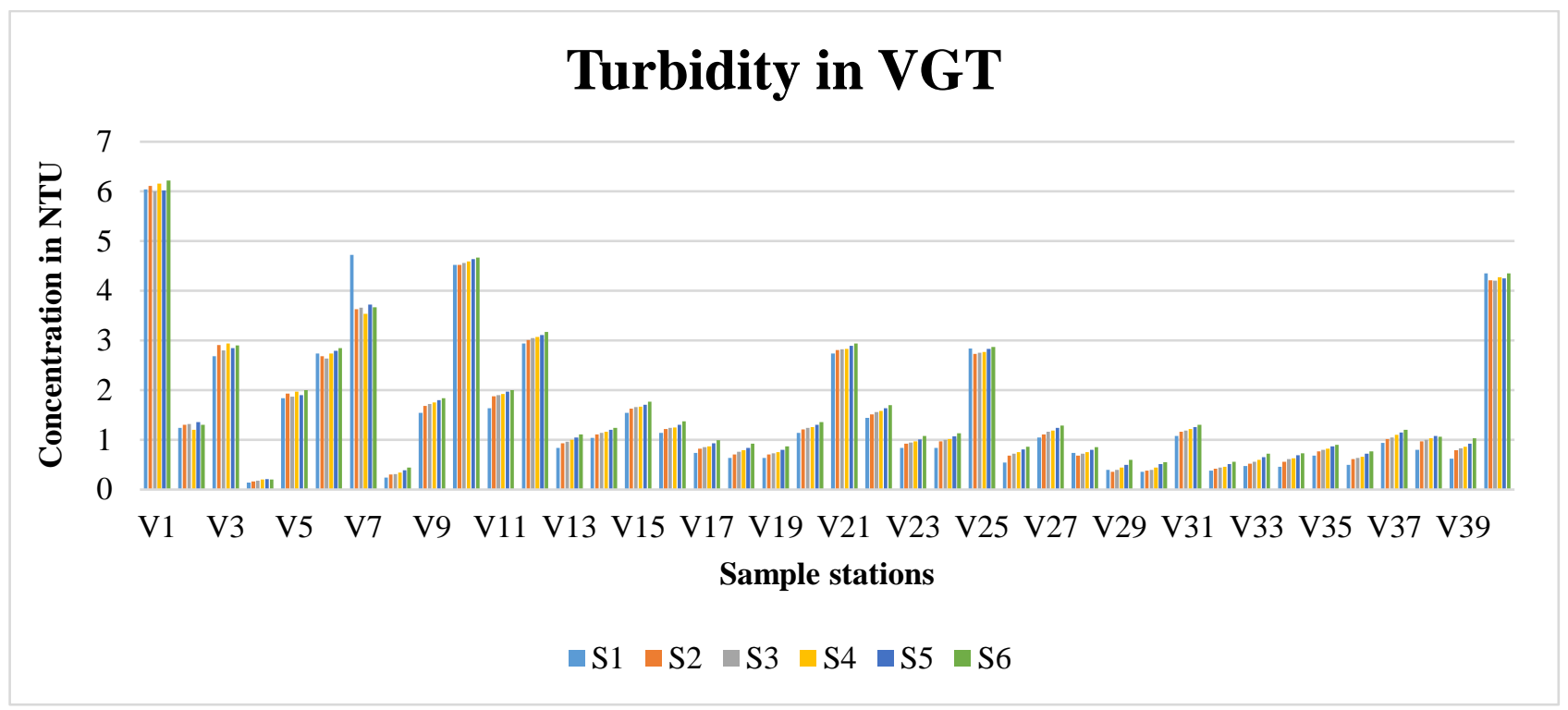

Figure 4: Variation of Turbidity with respect to pre and post monsoon seasons in water samples in the mandal of Veeraghattam

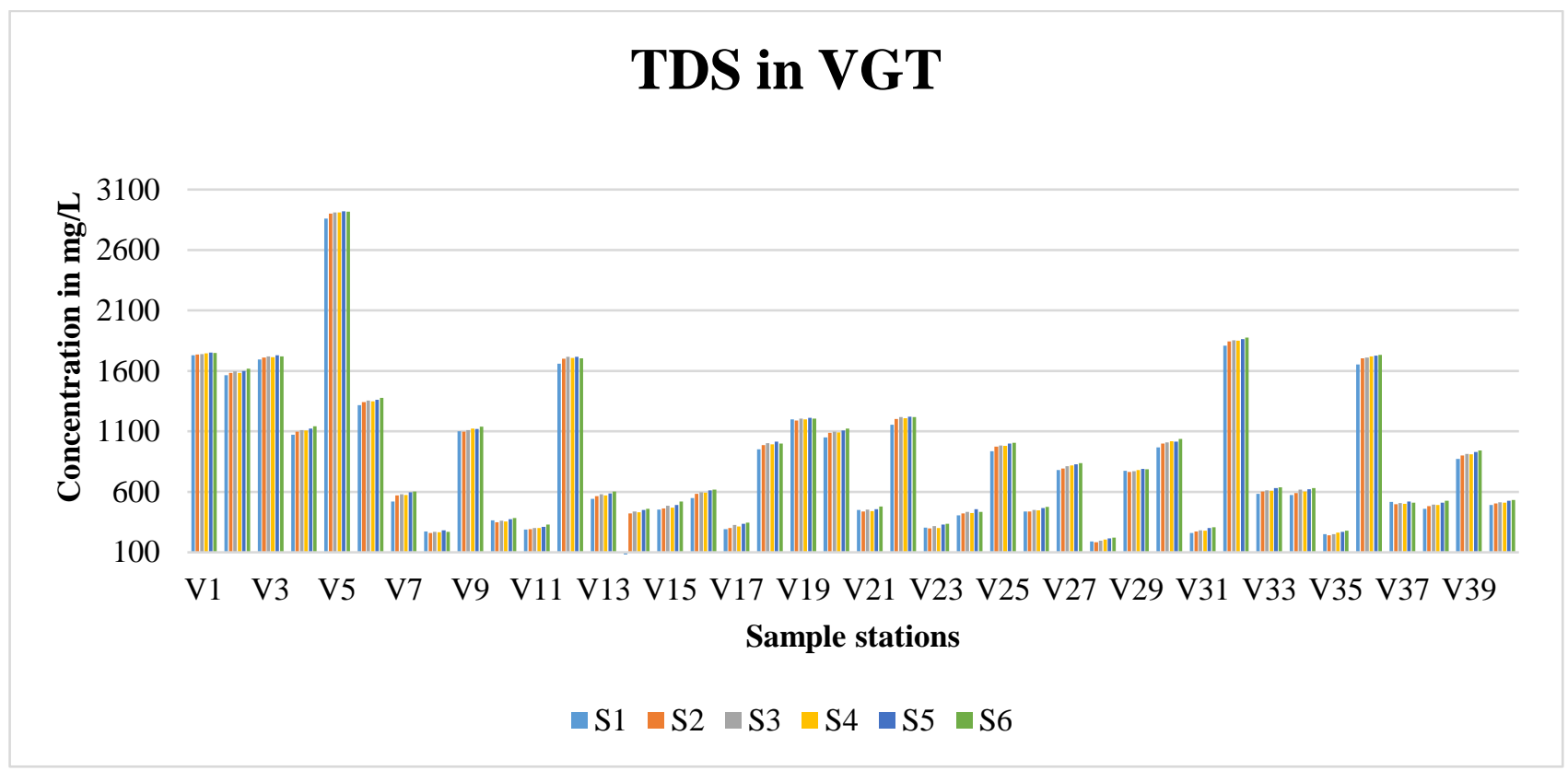

Figure 5: Variation of TDS in the seasons of selected water samples in the mandal of Veeraghattam

High Total Hardness (TH) leads to heart disease and kidney stones [24], formation in human beings and also leads to development of scales and sludges whenever this water is directly utilized without purification in Boilers and chance is leading to deteriorations pipes. The obtained results as per season variations are pictorially shown in Figure 6.

\subsection{Calcium}

$\mathrm{Ca}^{2+}$ is a foremost cation present in water which makes water hard. Desirable limit [16] of Calcium $(75 \mathrm{mg} / \mathrm{L})$ is essential to our body and due to the presence of an inadequate quantity of calcium leads to many problems in human beings. The concentration of calcium in the study zone is varied in between 9.19 to $185.4 \mathrm{mg} / \mathrm{L}$ in pre-monsoon with a mean value of $65.98 \mathrm{mg} / \mathrm{L}$ and 12.33 to $178.21 \mathrm{mg} / \mathrm{L}$ with an average value of $63.38 \mathrm{mg} / \mathrm{L}$ in after monsoon season respectively. The obtained experimental results reveal that a total of $7(17.5 \%)$ and ten samples $(25 \%)$ in pre and post-monsoon are beyond the permissible limits [16]. The variation of calcium in the groundwater in the selected locations of Veeraghattam Mandal is shown in Figure 7.

\subsection{Magnesium}

Magnesium is another highly copious inorganic ion existing in water [25]. $\mathrm{Mg}^{2+}$ ion in the samples are obtained in between 18.06 to $391.23 \mathrm{mg} / \mathrm{L}$ (with mean value $85.92 \mathrm{mg} / \mathrm{L}$ ) in before monsoon, and 25.25 to $387.78 \mathrm{mg} / \mathrm{L}$ was observed with an average value of $85.54 \mathrm{mg} / \mathrm{L}$ during post-monsoon. The ions of $\mathrm{Ca}^{2+}$ and $\mathrm{Mg}^{2+}$ are entered into the groundwater due to the presence of carbonate minerals, such as calcite and dolomite. Based on the well-established data [22] the acceptable range of Magnesium concentration is $30 \mathrm{mg} / \mathrm{L}$ for potable water. The experimental results indicate that in pre (39 samples, 97.5\%) and post-monsoon (33samples, 82.5\%) are respectively found in above the standard limits [22]. The obtained data related to the variation of magnesium ion 
concentrations in the samples in selected sites are shown in Figure 8 . In this research study, a significant observation was identified as compared to $\mathrm{Ca}^{2+}$ ion; the $\mathrm{Mg}^{2+}$ ion concentration in the samples was quite high. The concentration of $\mathrm{Mg}^{2+}$ ion is generally due to the weathering and leaking of magnesium minerals [26].

\subsection{Fluoride}

Fluoride [27] is the existence of water in dissimilar concentrations. As per the standard [22] references one mg/L as attainable and $1.50 \mathrm{mg} / \mathrm{L}$ as allowable frontier limits respectively for the ion of fluoride in drinking water. If human beings consume an excess amount of fluoride-containing water than the desirable limit for a long period, people suffer the diseases of fluorosis. In this present investigation in the selected sites, the groundwater samples had a maximum amount of fluoride concentration noticed in post-monsoon (the maximum value is $3.02 \mathrm{mg} / \mathrm{L}$ ) and $2.95 \mathrm{mg} / \mathrm{L}$ was observed in earlier monsoon. The concentration of fluoride in all the samples in selected locations in Veeraghattam Mandal was varied from $0.09-2.95 \mathrm{mg} / \mathrm{L}$ in the before monsoon with a mean value of $0.87 \mathrm{mg} / \mathrm{L}$ and also observed in post-monsoon these values were varied from $0.1-3.02 \mathrm{mg} / \mathrm{L}$ with an average value of $0.96 \mathrm{mg} / \mathrm{L}$. In this investigation, the results showed that the sample like V2, V9, V13, V17, V20, and V39 have more fluoride concentration than the desirable limit as per standard values $[16,22]$. Except for these samples in this research study, the other samples showed well within the limit. The concentration of fluoride ion against the samples are pictorially represented in Figure 9.

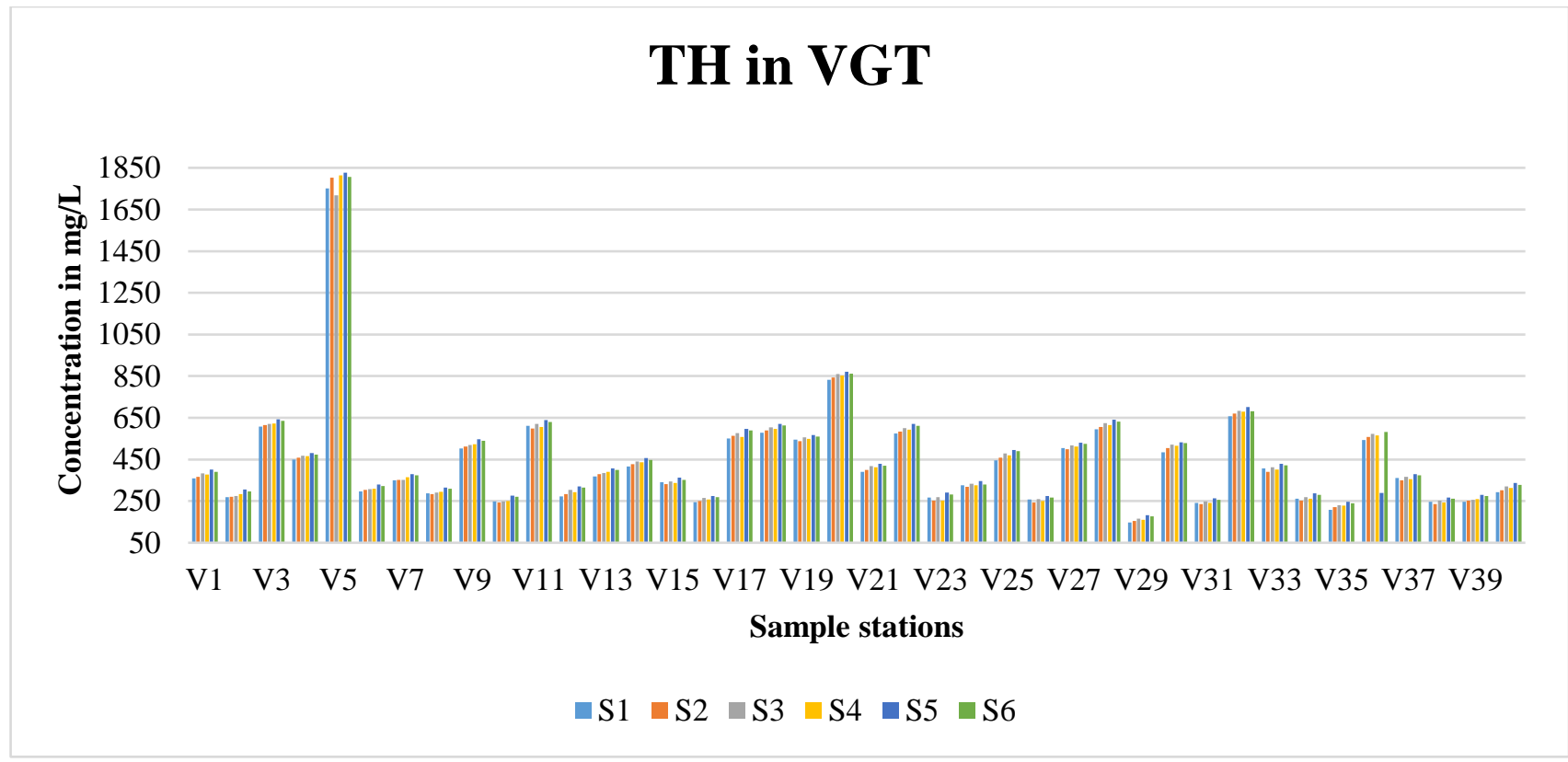

Figure 6: Variation of Total Hardness in the water samples in selected sites of Veeraghattam Mandal

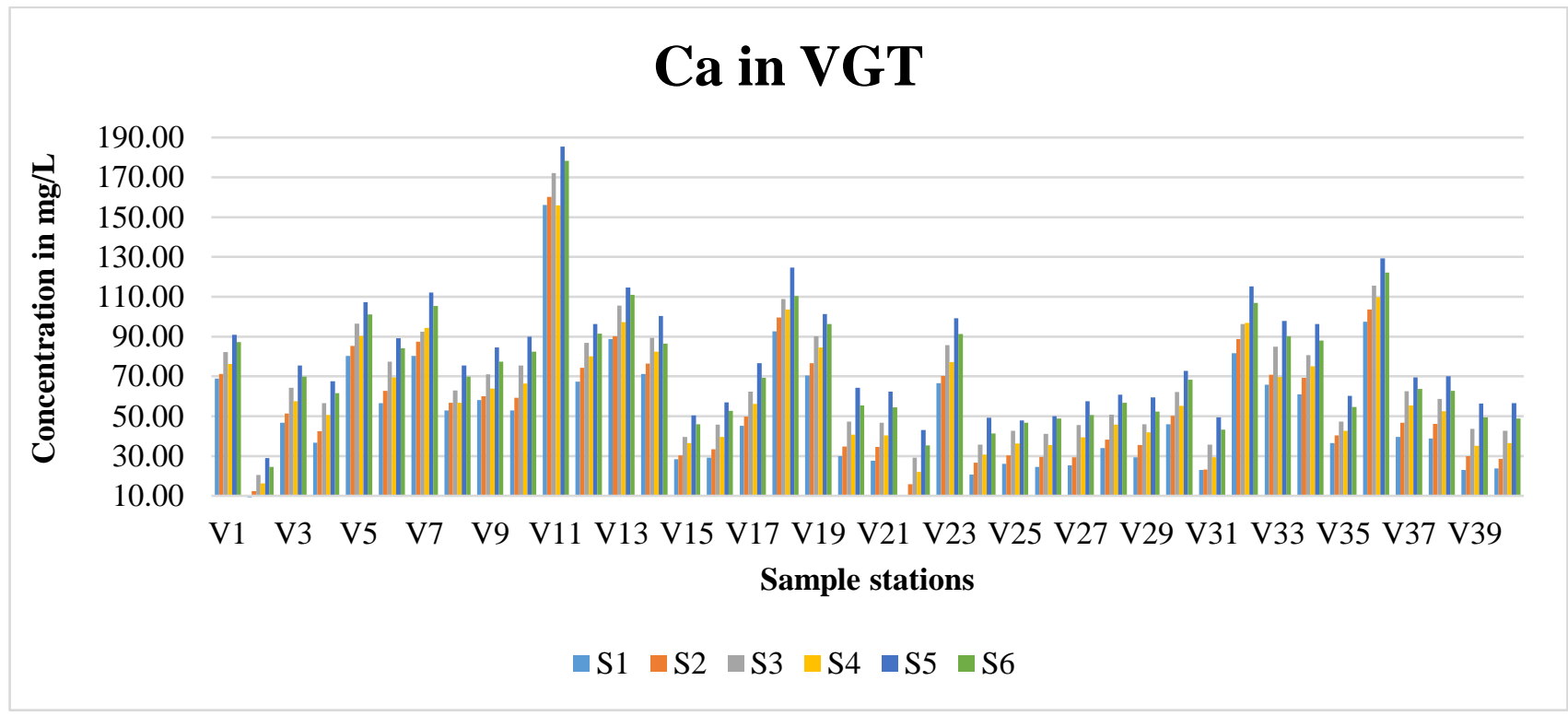

Figure 7: Variation of concentration of Calcium in water samples in selected sites of Veeraghattam Mandal 


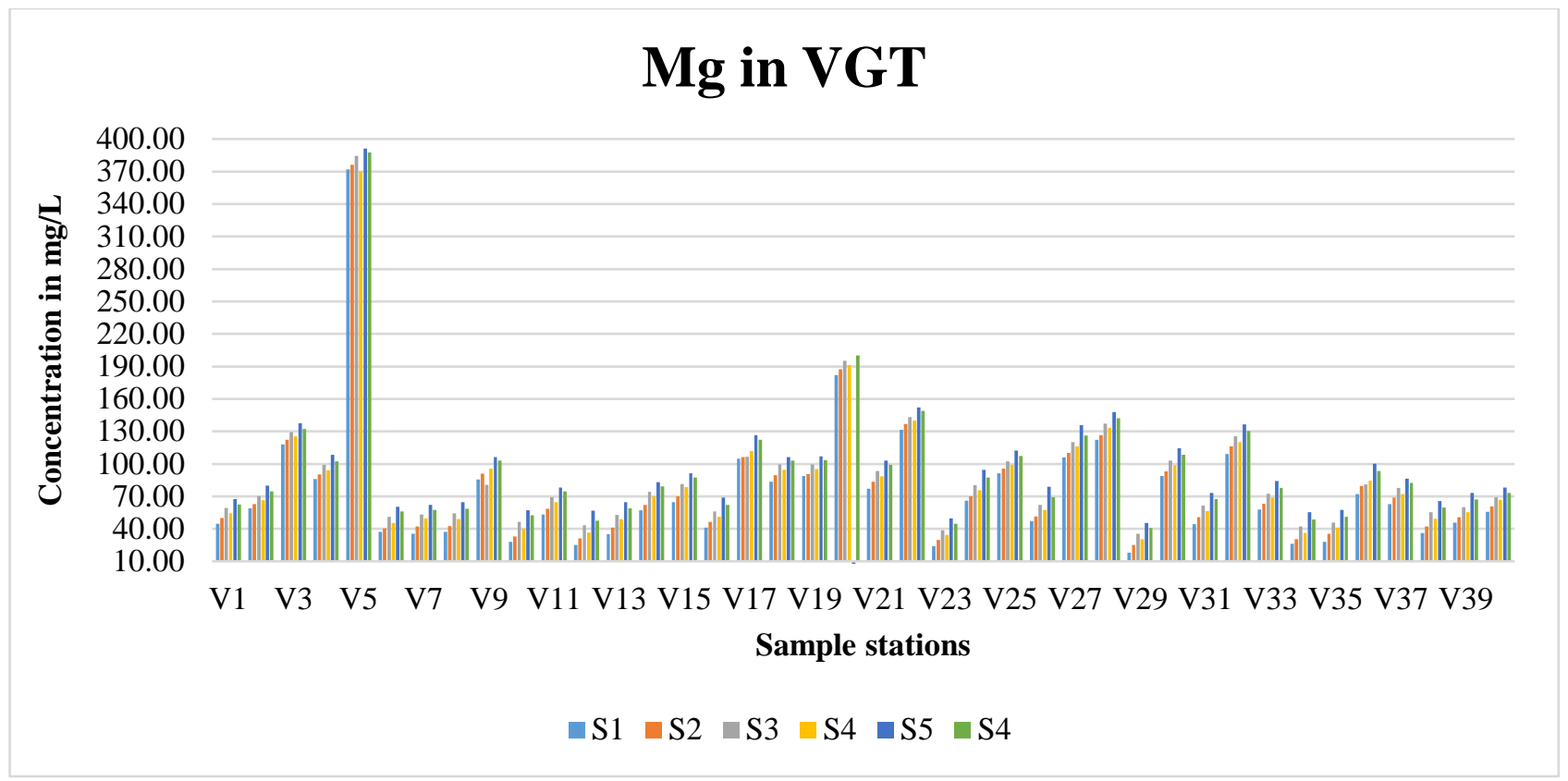

Figure 8: The variation of concentration of Magnesium in water samples in selected sites of Veeraghattam Mandal

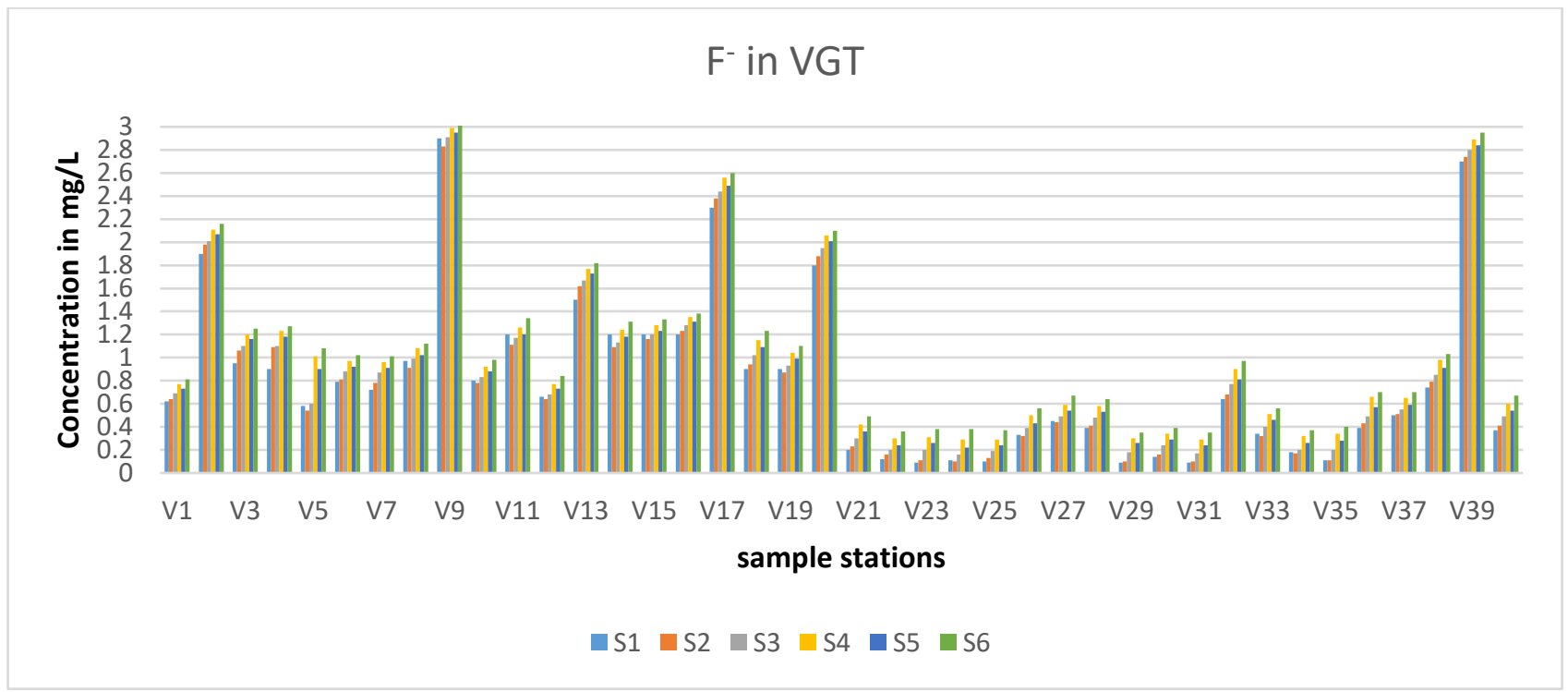

Figure 9: The concentration of Fluoride ion in selected sites in the mandal of Veeraghattam

\subsection{Chloride}

The amount of Chloride [11] is observed naturally in the groundwater due to the process weathering and leaching of sedimentary rocks, soils and salt dissolution. Chloride is frequently appended to $\mathrm{Na}$, as sodium chloride and the water was salty. In this research area, the $\left[\mathrm{Cl}^{-}\right]$in the groundwater samples are in-between 36 to $760 \mathrm{mg} / \mathrm{L}$ was obtained and having an average of $206.4 \mathrm{mg} / \mathrm{L}$ in the earlier monsoon. After this monsoon, the $\left[\mathrm{Cl}^{-}\right]$was observed between 39 to $774 \mathrm{mg} / \mathrm{L}$ with an average of $217.41 \mathrm{mg} / \mathrm{L}$. An observation was noted here under this study $\left[\mathrm{Cl}^{-}\right]$in post-monsoon was higher than to pre-monsoon. It was also found that in pre-monsoon (13 samples) and post-monsoon (14 samples) were showed the upper values than the standards [22], the remaining samples were within the standard limit $[16,22]$. If a person consumes more chloride-containing water regularly, person persons suffering from kidney and heart problems [28].The obtained chloride content in the sample areas is pictorially presented in Figure 10.

\subsection{Dissolved oxygen (DO)}

In this present investigation in the majority of the samples showed the concentration of DO was more than $6.0 \mathrm{mg} / \mathrm{L}$ and well agreement with established standards $[16,22]$. It indicates that in this research area in the selected sites we can say that the water samples are free from organic matter. Based on the parameter of DO as per the standards in this study area, the water was suitable for domestic usefulness.

\subsection{Total alkalinity (TA)}

Due to the presence of regular salts in the groundwater, the water shows alkalinity. It has the capacity to neutralize a powerful acid and due to the existence of $\mathrm{HCO}_{3}{ }^{-}, \mathrm{CO}_{3}{ }^{2-}$ and $\mathrm{OH}^{-}$ with $\mathrm{Na}, \mathrm{K}$ and $\mathrm{Ca}$ [29]. The Total Alkalinity was varied in the samples in selected sites of Veeraghattam Mandal is from 177 to $938 \mathrm{mg} / \mathrm{L}$ with an average of $408.1 \mathrm{mg} / \mathrm{L}$ in before monsoon. The values are obtained between 188 to $930 \mathrm{mg} / \mathrm{L}$ (average of $402.18 \mathrm{mg} / \mathrm{L}$ ) in the post monsoon. 


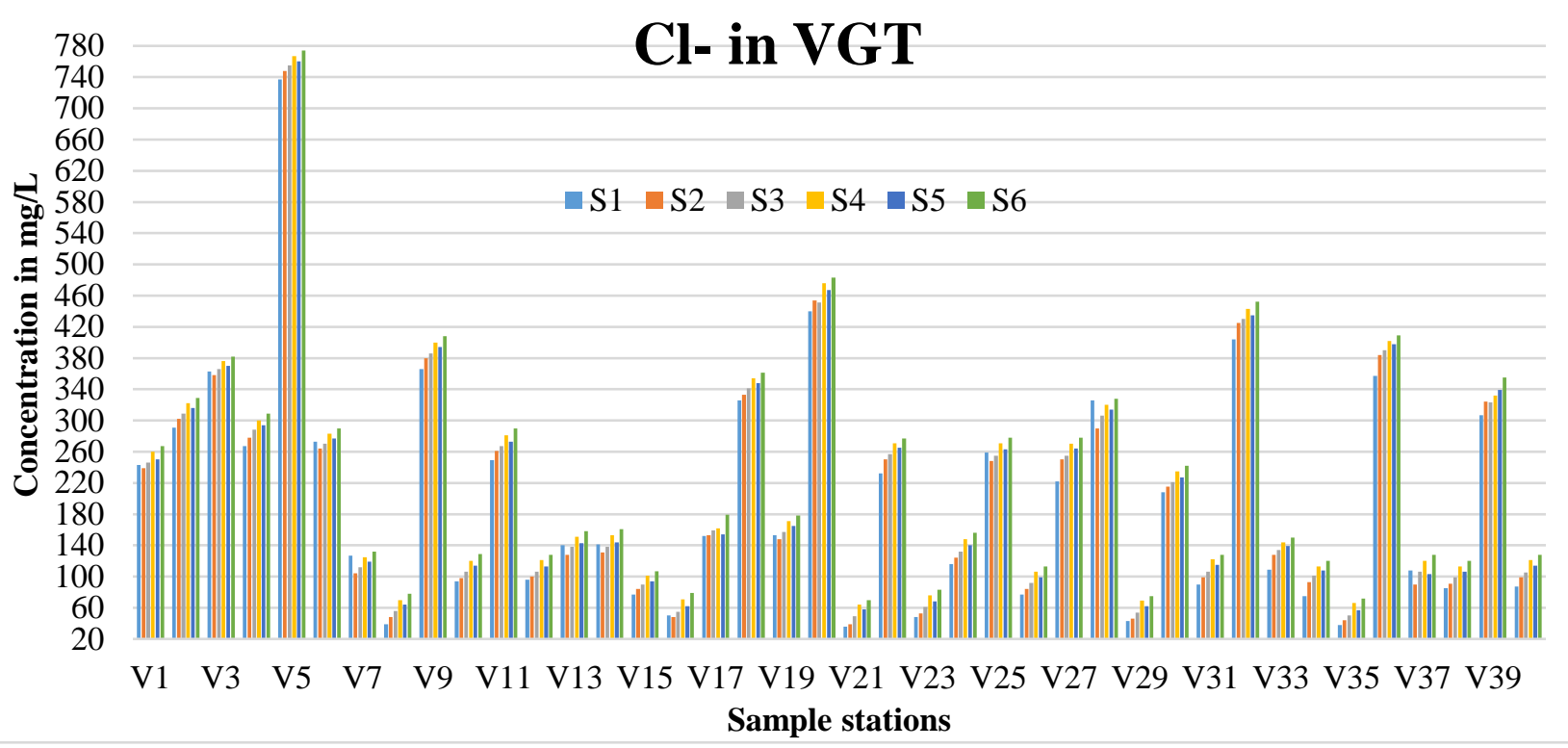

Figure 10: The concentration of Chloride ion $\left(\mathrm{Cl}^{-}\right)$variation ${ }^{\text {in }}$ water samples in selected zones of Veeraghattam Mandal

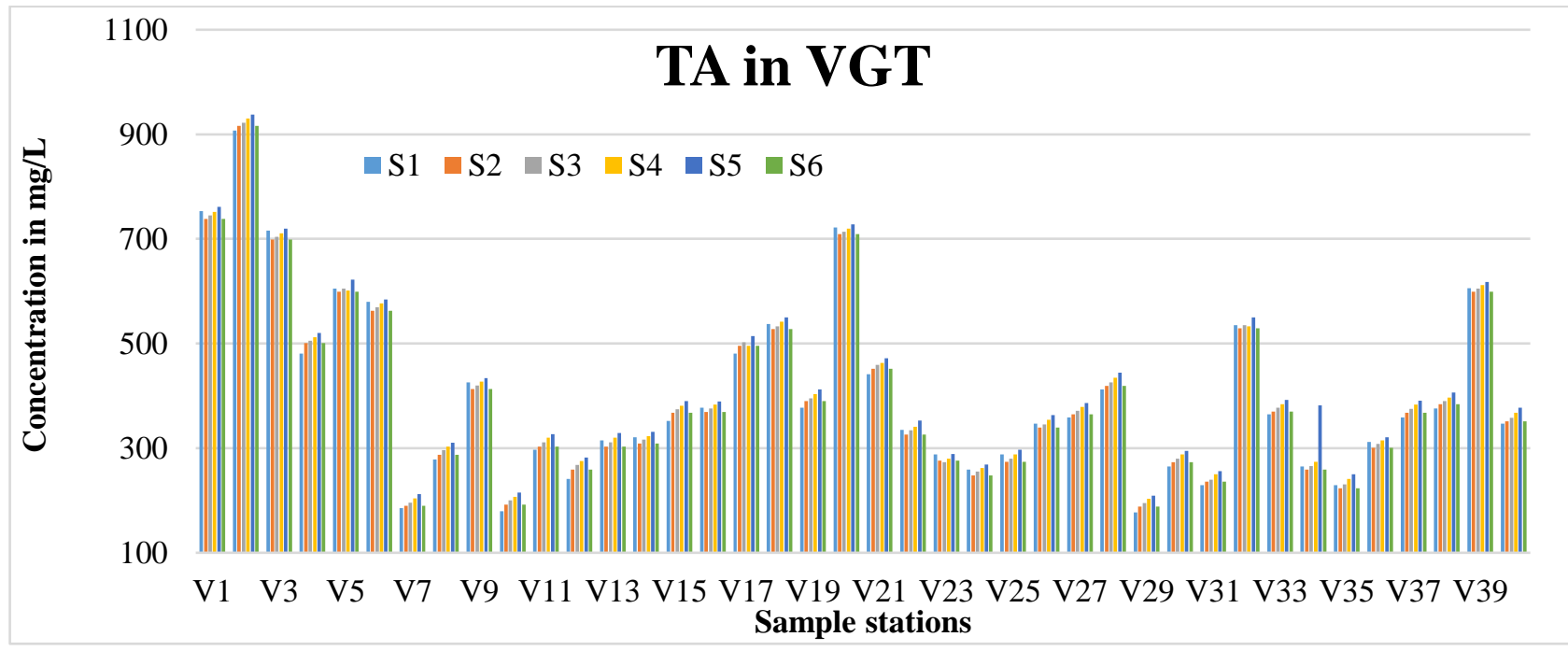

Figure 11: The concentration of Total alkalinity in selected sites in the villages of Veeraghattam Mandal

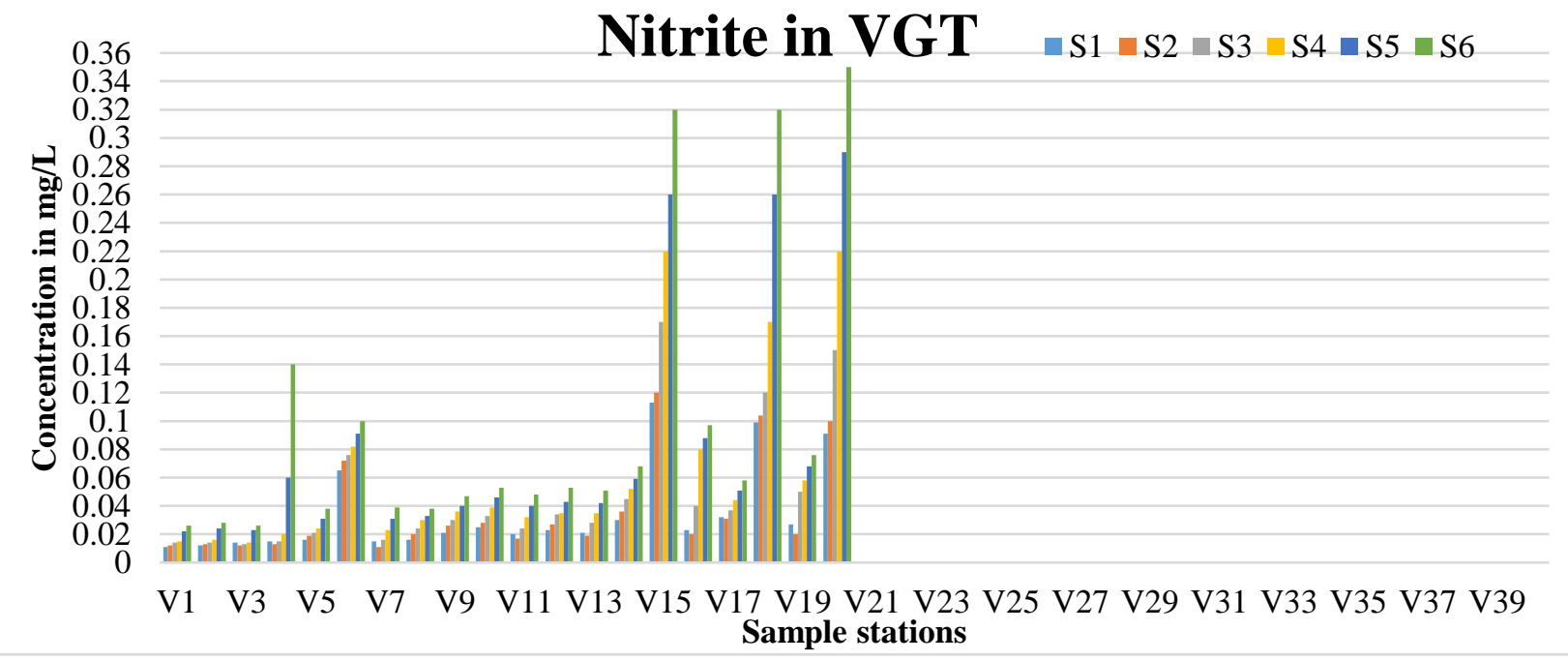

Figure 12: The concentration of Nitrite against sample stations of Veeraghattam Mandal 
Table 2: The mean, max, min and SD of Physico-chemical parameters for selected location samples in Veeraghattam Mandal during pre and post-monsoons

\begin{tabular}{|c|c|c|c|c|c|c|c|c|c|}
\hline \multirow{2}{*}{$\begin{array}{l}\text { VGT } \\
\text { Constituent }\end{array}$} & \multicolumn{4}{|c|}{ Pre-monsoon } & \multicolumn{4}{|c|}{ Post-monsoon } & \multirow{2}{*}{$\begin{array}{l}\text { Standard values as } \\
\text { per BIS }\end{array}$} \\
\hline & Average & Maximum & Minimum & $\begin{array}{l}\text { Standard } \\
\text { Deviation }\end{array}$ & Average & Maximum & Minimum & $\begin{array}{l}\text { Standard } \\
\text { Deviation } \\
\end{array}$ & \\
\hline $\mathrm{pH}$ & 7.36 & 8.06 & 6.56 & 0.35 & 7.47 & 8.10 & 6.61 & 0.36 & $6.5-8.5$ \\
\hline $\begin{array}{l}\text { Electrical } \\
\text { conductivity }\end{array}$ & 1261.63 & 3541 & 316 & 736.59 & 1265 & 3532 & 302 & 736.87 & 500 \\
\hline Turbidity & 1.56 & 6.04 & 0.14 & 1.31 & 1.60 & 6.22 & 0.16 & 1.30 & 5 \\
\hline $\begin{array}{l}\text { Total Dissolved } \\
\text { Solids }\end{array}$ & 864.18 & 2921 & 44 & 586.47 & 873.35 & 2916 & 184 & 585.95 & 500 \\
\hline $\mathrm{TH}$ & 447.53 & 1826 & 148 & 261.91 & 447.88 & 1813 & 154 & 267.70 & 300 \\
\hline Calcium & 65.98 & 185.4 & 9.19 & 31.64 & 63.38 & 178.21 & 12.33 & 29.75 & 75 \\
\hline Magnesium & 85.92 & 391.23 & 18.06 & 58.63 & 85.54 & 387.78 & 25.25 & 58.52 & 30 \\
\hline Fluoride ion & 0.87 & 2.95 & 0.09 & 0.71 & 0.96 & 3.02 & 0.1 & 0.71 & 1.5 \\
\hline Chloride ion & 206.4 & 760 & 36 & 146.28 & 217.41 & 774 & 39 & 147.29 & 250 \\
\hline DO & 5.64 & 8.14 & 3.36 & 1.25 & 5.65 & 8.08 & 3.32 & 1.21 & - \\
\hline Total Alkalinity & 408.14 & 938 & 177 & 166.59 & 402.18 & 930 & 188 & 165.77 & 200 \\
\hline Nitrite & 0.03 & 0.29 & 0.011 & 0.05 & 0.03 & 0.35 & 0.011 & 0.06 & 0.02 \\
\hline
\end{tabular}

*Except $\mathrm{pH}$, Electrical conductivity and Turbidity, the constituents are in $\mathrm{mg} / \mathrm{L}$

Based on the experimental results indicated that most of the samples display more alkalinity in both the seasons except the samples of V7, V10, and V29 [16, 22]. The minimum quantity of alkalinity present in water it can cause corrosiveness and irritation of the eyes. Due to more alkalinity, it has a sense of taste like soda and it might be the foundation for dry-skin and also can cause to formation of scaling on through water distribution system [25]. Variation of alkalinity in the selected sites in the Mandal is shown in Figure 11.

\subsection{Nitrite}

The concentration of nitrite was obtained between 0.011 to $0.45 \mathrm{mg} / \mathrm{L}$ in pre-monsoon and 0.011 to $0.48 \mathrm{mg} / \mathrm{L}$ in post monsoon. The results indicated that in both the seasons the nitrite concentration was maintained the same tempo. According to established standards [16] in drinking water nitrite concentration should be required $0.02 \mathrm{mg} / \mathrm{L}$, above the concentration of $1.0 \mathrm{mg} / \mathrm{L}$ of nitrite containing water is not used for infant feeding. All the groundwater samples in the present analysis are within the accessible range. Variation of nitrite in the selected locations is shown in Figure 12 and the studied physicochemical parameters in this research work the mean values in this study are presented in Table 2.

\section{Water Quality index (WQI)}

Out of 13 parameters/constituents analyzed in the selected sites, 10 parameters were [Table 3] taken for calculating WQI [30]. The quality of Index for water is assumed by way of a ranking reflecting the mingled effect of different drinking water quality parameters on the entire quality of drinking water. The WQI was computed for the idea of understanding the appropriateness of water instead of human utilization in the selected sites in the villages of Veeraghattam Mandal. It is assumed that the weights for several drinking water worth of parameters are inversely proportionate to the standards for the relevant parameters [30]. Weighted arithmetic index method of WQI proposed by Brown (1972) stood applied [31] to evaluate the water quality rank of the groundwater [32]. The parameters like EC, pH, TDS, TH, Ca (II), $\mathrm{Mg}$ (II), $\mathrm{Cl}^{-}, \mathrm{F}^{-}, \mathrm{NO}_{2}{ }^{-}$and TA were used to calculate WQI of groundwater in selected locations in the villages of Veeraghattam Mandal.

Table 3: Relative Weight of parameters

\begin{tabular}{lll}
\hline Parameter & As per BIS & Wi \\
\hline $\mathrm{pH}$ & 8.5 & 0.058415 \\
$\mathrm{EC}$ & 500 & 0.000993 \\
$\mathrm{TDS}$ & 500 & 0.000993 \\
$\mathrm{TH}$ & 300 & 0.001655 \\
$\mathrm{Ca}$ & 75 & 0.00662 \\
$\mathrm{Mg}$ & 30 & 0.016551 \\
$\mathrm{~F}^{-}$ & 1.2 & 0.413774 \\
$\mathrm{Cl}^{-}$ & 250 & 0.001986 \\
Total alkalinity & 200 & 0.002483 \\
Nitrite & 1 & 0.496529 \\
& & $\sum \mathrm{W}_{\mathrm{i}}=1$ \\
\hline
\end{tabular}

$W Q I$ is calculated by using the following formula:

$W Q I=\Sigma Q i W i / \Sigma W i$

where $Q \mathrm{i}$ is the value ranking of $\mathrm{i}^{\text {th }}$ water value parameter and $W i$ is the component weight of the $n$th water quality parameter. The $Q \mathrm{i}$ is calculated by the following formula:

$Q \mathrm{i}=100 *\left[\left(V_{\mathrm{i}}-V_{\mathrm{o}}\right) /\left(V_{\mathrm{s}}-V_{\mathrm{o}}\right)\right]$

where $V_{\mathrm{i}}$ is the actual amount of $i^{\text {th }}$ parameter present, $V_{\mathrm{o}}$ is the ideal value of the parameter, $V_{\mathrm{o}}=0$, except for $\mathrm{pH}\left(V_{\mathrm{o}}=7\right)$ and $V \mathrm{~s}$ is the standard allowable value for the $i^{\text {th }}$ water quality parameter. Unit weight $(W i)$ is estimated by using the following formula: 
$W i=\mathrm{k} / V_{\mathrm{i}}$

here $\mathrm{k}$ is proportionality constant, and it is estimated by using the following equation:

$K=1 / \Sigma V_{\mathrm{s}}=1,2 \ldots n$

Based on the obtained WQI results, it was observed that the variations of WQI of the groundwater are noticed within the range from 34.55 to 46.33 in the selected sites in rural communities in the Mandal of Veeraghattam. The obtained results revealed that in the majority of the locations in the research area represents that the quality of groundwater is good for potable as well as agriculture purpose [32-33].

\section{Correlation}

The correlation studies are attempted for this investigation results to know the degree of a linear relationship between any two of the water quality parameters. In this study different correlations are studied [Tables 4 to 9] like perfectly correlated $\left(\mathrm{R}^{2}=1\right)$, very strongly correlated $\left( \pm 0.9 \leq \mathrm{R}^{2} \leq 1\right)$, strongly correlated $\left( \pm 0.7 \leq \mathrm{R}^{2}< \pm 0.9\right)$, moderately correlated $\left( \pm 0.5 \leq \mathrm{R}^{2}\right.$ $< \pm 0.9)$, and $\left(\mathrm{R}^{2}< \pm 0.5\right)$ as poorly correlated [34].

In Veeraghattam Mandal for the located samples, the correlation between parameters is Calcium, TA, and $\mathrm{NO}_{2}^{-}$are did not strongly correlated with any of the parameters. $\mathrm{pH}$ is poorly correlated with $\mathrm{F}^{-}, \mathrm{NO}_{2}^{-}$, and moderately correlated with DO. EC is very strongly correlated with $\mathrm{Cl}^{-}, \mathrm{TA}, \mathrm{TDS}, \mathrm{TH}$, and moderately correlated by way of $\mathrm{Mg}$. TDS is strongly correlated with $\mathrm{Cl}^{-}$, and reasonably with $\mathrm{TH}, \mathrm{TA}$, and $\mathrm{Mg}$. However, TDS is high due to the existence of Magnesium dissolved salts. A very Solid positive correlation was noticed between total hardness and $\mathrm{Mg}$, and it is strongly correlated with $\mathrm{Cl}^{-}$. It signifies that hardness was due to mostly the dissolved $\mathrm{Mg}$ salts. A strong correlation with chloride also indicates the presence of permanent hardness in groundwater. $\mathrm{F}^{-}$and $\mathrm{Cl}^{-}$were moderately correlated with TA.

Table 4: Correlation of Physico-chemical constituents for selected samples in Veeraghattam Mandal (December 2013)

\begin{tabular}{|c|c|c|c|c|c|c|c|c|c|c|c|c|}
\hline & $\mathrm{EC}$ & $\mathrm{pH}$ & Turbidity & TDS & $\mathrm{TH}$ & $\mathrm{Ca}$ & $\mathrm{Mg}$ & $\mathrm{F}^{-}$ & $\mathrm{Cl}^{-}$ & DO & $\begin{array}{l}\text { Total } \\
\text { alkalinity }\end{array}$ & Nitrite \\
\hline $\mathrm{EC}$ & 1.00 & & & & & & & & & & & \\
\hline $\mathrm{pH}$ & 0.06 & 1.00 & & & & & & & & & & \\
\hline Turbidity & 0.11 & 0.21 & 1.00 & & & & & & & & & \\
\hline TDS & 0.79 & 0.02 & 0.18 & 1.00 & & & & & & & & \\
\hline $\mathrm{TH}$ & 0.72 & -0.21 & -0.04 & 0.61 & 1.00 & & & & & & & \\
\hline $\mathrm{Ca}$ & 0.16 & -0.08 & 0.06 & 0.16 & 0.31 & 1.00 & & & & & & \\
\hline $\mathrm{Mg}$ & 0.70 & -0.20 & -0.06 & 0.59 & 0.96 & 0.03 & 1.00 & & & & & \\
\hline $\mathrm{F}^{-}$ & 0.33 & 0.43 & -0.07 & 0.07 & 0.08 & 0.07 & 0.06 & 1.00 & & & & \\
\hline $\mathrm{Cl}^{-}$ & 0.94 & -0.11 & 0.00 & 0.75 & 0.83 & 0.24 & 0.81 & 0.29 & 1.00 & & & \\
\hline DO & 0.12 & 0.37 & 0.16 & 0.06 & 0.33 & -0.13 & 0.38 & -0.03 & 0.18 & 1.00 & & \\
\hline $\begin{array}{l}\text { Total } \\
\text { alkalinity }\end{array}$ & 0.81 & 0.20 & 0.10 & 0.57 & 0.36 & -0.10 & 0.41 & 0.47 & 0.61 & 0.00 & 1.00 & \\
\hline Nitrite & 0.20 & 0.33 & 0.05 & 0.05 & 0.16 & 0.14 & 0.13 & 0.38 & 0.17 & 0.25 & 0.27 & 1.00 \\
\hline
\end{tabular}

Table 5: Correlation of Physico-chemical constituents for selected samples in Veeraghattam Mandal (June 2014)

\begin{tabular}{llllllllllll}
\hline & $E C$ & $p H$ & Turbidity & $T D S$ & $T H$ & $C a$ & $M g$ & $F^{-}$ & $C l^{-}$ & DO & $\begin{array}{l}\text { Total } \\
\text { alkalinity }\end{array}$ Nitrite \\
\hline EC & 1.00 & & & & & & & & & & \\
pH & 0.10 & 1.00 & & & & & & & & & \\
Turbidity & 0.13 & 0.20 & 1.00 & & & & & & & & \\
TDS & 0.79 & 0.05 & 0.20 & 1.00 & & & & & & & \\
TH & 0.72 & -0.11 & -0.02 & 0.63 & 1.00 & & & & & & \\
Ca & 0.16 & -0.04 & 0.06 & 0.18 & 0.30 & 1.00 & & & & & \\
Mg & 0.70 & -0.12 & -0.05 & 0.60 & 0.96 & 0.03 & 1.00 & & & & \\
F $^{-}$ & 0.36 & 0.41 & -0.05 & 0.09 & 0.08 & 0.04 & 0.06 & 1.00 & & & \\
Cl- & 0.93 & -0.04 & -0.01 & 0.77 & 0.83 & 0.23 & 0.80 & 0.30 & 1.00 & & \\
DO & 0.07 & 0.50 & 0.12 & 0.01 & 0.26 & -0.15 & 0.30 & -0.05 & 0.09 & 1.00 & \\
Total & 0.81 & 0.19 & 0.14 & 0.56 & 0.36 & -0.11 & 0.40 & 0.50 & 0.60 & -0.03 & 1.00 \\
alkalinity & 0.22 & 0.39 & 0.06 & 0.07 & 0.16 & 0.12 & 0.13 & 0.37 & 0.18 & 0.28 & 0.28 \\
Nitrite & 0.28 &
\end{tabular}


Table 6: Correlation of Physico-chemical constituents for selected samples in Veeraghattam Mandal(December 2014)

\begin{tabular}{|c|c|c|c|c|c|c|c|c|c|c|c|c|}
\hline & $E C$ & $p H$ & Turbidity & $T D S$ & $T H$ & $\mathrm{Ca}$ & $M g$ & $F^{-}$ & $\mathrm{Cl}^{-}$ & $D O$ & $\begin{array}{l}\text { Total } \\
\text { alkalinity }\end{array}$ & Nitrite \\
\hline $\mathrm{EC}$ & 1.00 & & & & & & & & & & & \\
\hline $\mathrm{pH}$ & 0.04 & 1.00 & & & & & & & & & & \\
\hline Turbidity & 0.12 & 0.19 & 1.00 & & & & & & & & & \\
\hline TDS & 0.79 & 0.02 & 0.18 & 1.00 & & & & & & & & \\
\hline TH & 0.72 & -0.17 & -0.04 & 0.62 & 1.00 & & & & & & & \\
\hline $\mathrm{Ca}$ & 0.17 & -0.07 & 0.06 & 0.18 & 0.30 & 1.00 & & & & & & \\
\hline $\mathrm{Mg}$ & 0.69 & -0.18 & -0.06 & 0.59 & 0.96 & 0.03 & 1.00 & & & & & \\
\hline $\mathrm{F}^{-}$ & 0.36 & 0.41 & -0.05 & 0.09 & 0.08 & 0.04 & 0.02 & 1.00 & & & & \\
\hline $\mathrm{Cl}^{-}$ & 0.93 & -0.09 & -0.02 & 0.77 & 0.84 & 0.23 & 0.79 & 0.29 & 1.00 & & & \\
\hline DO & -0.05 & 0.54 & 0.07 & -0.13 & 0.05 & -0.19 & 0.10 & -0.02 & -0.06 & 1.00 & & \\
\hline $\begin{array}{l}\text { Total } \\
\text { alkalinity }\end{array}$ & 0.81 & 0.16 & 0.13 & 0.56 & 0.36 & -0.12 & 0.39 & 0.50 & 0.60 & -0.08 & 1.00 & \\
\hline Nitrite & 0.18 & 0.33 & 0.03 & 0.05 & 0.17 & 0.08 & 0.15 & 0.37 & 0.14 & 0.33 & 0.26 & 1.00 \\
\hline
\end{tabular}

Table 7: Correlation of Physico-chemical constituents for selected samples in Veeraghattam Mandal (June 2015)

\begin{tabular}{|c|c|c|c|c|c|c|c|c|c|c|c|c|}
\hline & $E C$ & $p H$ & Turbidity & $T D S$ & $T H$ & $\mathrm{Ca}$ & $M g$ & $F^{-}$ & $\mathrm{Cl}^{-}$ & $D O$ & $\begin{array}{l}\text { Total } \\
\text { alkalinity }\end{array}$ & Nitrite \\
\hline $\mathrm{EC}$ & 1.00 & & & & & & & & & & & \\
\hline $\mathrm{pH}$ & 0.07 & 1.00 & & & & & & & & & & \\
\hline Turbidity & 0.13 & 0.22 & 1.00 & & & & & & & & & \\
\hline TDS & 0.79 & 0.05 & 0.19 & 1.00 & & & & & & & & \\
\hline $\mathrm{TH}$ & 0.73 & -0.14 & -0.02 & 0.63 & 1.00 & & & & & & & \\
\hline $\mathrm{Ca}$ & 0.17 & -0.10 & 0.07 & 0.20 & 0.30 & 1.00 & & & & & & \\
\hline $\mathrm{Mg}$ & 0.70 & -0.14 & -0.05 & 0.59 & 0.96 & 0.04 & 1.00 & & & & & \\
\hline $\mathrm{F}^{-}$ & 0.39 & 0.36 & -0.07 & 0.13 & 0.13 & 0.05 & 0.12 & 1.00 & & & & \\
\hline $\mathrm{Cl}^{-}$ & 0.93 & -0.07 & -0.01 & 0.77 & 0.84 & 0.24 & 0.81 & 0.33 & 1.00 & & & \\
\hline DO & 0.07 & 0.49 & 0.12 & 0.00 & 0.25 & -0.17 & 0.30 & -0.05 & 0.09 & 1.00 & & \\
\hline $\begin{array}{l}\text { Total } \\
\text { alkalinity }\end{array}$ & 0.80 & 0.16 & 0.14 & 0.55 & 0.35 & -0.12 & 0.39 & 0.51 & 0.59 & -0.03 & 1.00 & \\
\hline Nitrite & 0.16 & 0.31 & 0.00 & 0.02 & 0.16 & 0.07 & 0.16 & 0.37 & 0.15 & 0.32 & 0.26 & 1.00 \\
\hline
\end{tabular}

Table 8: Correlation of Physico-chemical constituents for selected samples in Veeraghattam Mandal (December 2015)

\begin{tabular}{|c|c|c|c|c|c|c|c|c|c|c|c|c|}
\hline & $E C$ & $p H$ & Turbidity & $T D S$ & $T H$ & $\mathrm{Ca}$ & $M g$ & $F^{-}$ & $\mathrm{Cl}^{-}$ & $D O$ & $\begin{array}{l}\text { Total } \\
\text { alkalinity }\end{array}$ & Nitrite \\
\hline $\mathrm{EC}$ & 1.00 & & & & & & & & & & & \\
\hline $\mathrm{pH}$ & 0.11 & 1.00 & & & & & & & & & & \\
\hline Turbidity & 0.12 & 0.28 & 1.00 & & & & & & & & & \\
\hline TDS & 0.79 & 0.07 & 0.18 & 1.00 & & & & & & & & \\
\hline $\mathrm{TH}$ & 0.70 & -0.06 & -0.01 & 0.58 & 1.00 & & & & & & & \\
\hline $\mathrm{Ca}$ & 0.15 & -0.01 & 0.06 & 0.16 & 0.25 & 1.00 & & & & & & \\
\hline $\mathrm{Mg}$ & 0.69 & -0.15 & -0.08 & 0.59 & 0.96 & 0.03 & 1.00 & & & & & \\
\hline $\mathrm{F}^{-}$ & 0.39 & 0.38 & -0.06 & 0.12 & 0.14 & 0.06 & 0.09 & 1.00 & & & & \\
\hline $\mathrm{Cl}^{-}$ & 0.93 & -0.04 & -0.02 & 0.77 & 0.80 & 0.23 & 0.80 & 0.33 & 1.00 & & & \\
\hline DO & -0.04 & 0.52 & 0.06 & -0.13 & 0.08 & -0.20 & 0.09 & -0.03 & -0.05 & 1.00 & & \\
\hline $\begin{array}{l}\text { Total } \\
\text { alkalinity }\end{array}$ & 0.80 & 0.17 & 0.12 & 0.56 & 0.37 & -0.12 & 0.38 & 0.50 & 0.59 & -0.10 & 1.00 & \\
\hline Nitrite & 0.21 & 0.29 & -0.02 & 0.05 & 0.20 & 0.09 & 0.16 & 0.36 & 0.18 & 0.31 & 0.28 & 1.00 \\
\hline
\end{tabular}


Table 9: Correlation of Physico-chemical constituents for selected samples in Veeraghattam Mandal (June 2016)

\begin{tabular}{|c|c|c|c|c|c|c|c|c|c|c|c|c|}
\hline & $E C$ & $p H$ & Turbidity & $T D S$ & $T H$ & $\mathrm{Ca}$ & $M g$ & $F^{-}$ & $\mathrm{Cl}^{-}$ & $D O$ & $\begin{array}{l}\text { Total } \\
\text { alkalinity }\end{array}$ & Nitrite \\
\hline EC & 1.00 & & & & & & & & & & & \\
\hline $\mathrm{pH}$ & 0.05 & 1.00 & & & & & & & & & & \\
\hline Turbidity & 0.12 & 0.24 & 1.00 & & & & & & & & & \\
\hline TDS & 0.79 & 0.01 & 0.18 & 1.00 & & & & & & & & \\
\hline TH & 0.72 & -0.17 & -0.03 & 0.63 & 1.00 & & & & & & & \\
\hline $\mathrm{Ca}$ & 0.15 & -0.08 & 0.07 & 0.17 & 0.30 & 1.00 & & & & & & \\
\hline $\mathrm{Mg}$ & 0.69 & -0.17 & -0.07 & 0.59 & 0.96 & 0.03 & 1.00 & & & & & \\
\hline $\mathrm{F}^{-}$ & 0.40 & 0.32 & -0.06 & 0.13 & 0.14 & 0.06 & 0.11 & 1.00 & & & & \\
\hline $\mathrm{Cl}^{-}$ & 0.93 & -0.10 & -0.02 & 0.77 & 0.83 & 0.22 & 0.80 & 0.35 & 1.00 & & & \\
\hline DO & -0.03 & 0.57 & 0.07 & -0.13 & 0.05 & -0.19 & 0.09 & -0.03 & -0.05 & 1.00 & & \\
\hline $\begin{array}{l}\text { Total } \\
\text { alkalinity }\end{array}$ & 0.80 & 0.12 & 0.13 & 0.56 & 0.36 & -0.13 & 0.39 & 0.51 & 0.60 & -0.08 & 1.00 & \\
\hline Nitrite & 0.23 & 0.27 & -0.04 & 0.05 & 0.18 & 0.06 & 0.17 & 0.35 & 0.19 & 0.30 & 0.29 & 1.00 \\
\hline
\end{tabular}

\section{Conclusion}

The computed WQI values were placed from 34.55 to 46.33. It indicates that gradually the quality of water availability is decreasing. The obtained value of the Water Quality Index in this research work affected due to growing the amounts of parameters like Total Dissolved Solids, Fluoride, Total Hardness and Magnesium in the groundwater. The outcome of the correlation analysis points out a powerful positive correlation between $\mathrm{Mg}$ and $\mathrm{Cl}^{-}$which is tremendously correlated and showed that the hardness is stable. Moreover, the amount fluoride in V2, V9, V13, V17, V20, and V39 samples have higher than the desirable limit [16, 22]. The established outcomes revealed that Water Quality Index concerning, water samples of the selected sites need specific treatment earlier than the utilization and it requires to safeguarding from the elements of infection too.

\section{Acknowledgement}

The author wishes to acknowledge the management of $G$ M R Institute of Technology, Rajam for providing all facilities to carry out the research work.

\section{Ethical issue}

Authors are aware of, and comply with, best practice in publication ethics specifically with regard to authorship (avoidance of guest authorship), dual submission, manipulation of figures, competing interests and compliance with policies on research ethics. Authors adhere to publication requirements that submitted work is original and has not been published elsewhere in any language.

\section{Competing interests}

The authors declare that there is no conflict of interest that would prejudice the impartiality of this scientific work.

\section{Authors' contribution}

All authors of this study have a complete contribution for data collection, data analyses and manuscript writing.

\section{References}

1. Li, P., \& Wu, J. Drinking water quality and public health. Exposure and Health, 2019 11(2), 73-79. https://doi.org/10.1007/s12403-019-00299-8

2. Elayaraj, B., \& Selvaraju, M. Seasonal Variations in PhysicoChemical Parameters of Sri Kamatchiamman Temple Pond Chidambaram Taluk, Tamilnadu. J. Environ. Treat. Tech, 2015, 3(3), 126-133.

3. Garba, T., Ilelah, K. G., Kwari, M. A., Sadiq, L. S., Sani, M. J., \& Zulkarnain, O. L. Assessment of Open Well Water Contamination in High Density Residential Area. J. Environ. Treat. Tech., 2016, 4(2), 37-40.

4. Hossain, L., \& Islam, K. Assessment of Water Quality in Chandpur District of Bangladesh. J Enviro. Treat. Tech, 2013, 1(2), 91-100.

5. Ghalib, H. B. Groundwater chemistry evaluation for drinking and irrigation utilities in east Wasit province, central Iraq. Applied Water Science, 2017, 7(7), 3447-3467. https://doi.org/10.1007/s13201-017-0575-8

6. Li, P., Tian, R., Xue, C., \& Wu, J. Progress, opportunities, and key fields for groundwater quality research under the impacts of human activities in China with a special focus on western China. Environmental Science and Pollution Research, 2017, 24(15), 13224-13234. https://doi.org/10.1007/s11356-017-8753-7

7. Lefort, R. "Down to the last drop." UNESCO Sources, Vol. 84(7), 2006.

8. Subba Rao, N. Groundwater quality from a part of Prakasam district, Andhra Pradesh, India. Applied Water Science, 2018, 8(1). https://doi.org/10.1007/s13201-018-0665-2

9. Mogasale, V. V., Ramani, E., Mogasale, V., Park, J. Y., \& Wierzba, T. F. Estimating typhoid fever risk associated with lack of access to safe water: A systematic literature review. Journal of Environmental and Public Health, 2018, 2018, 1-14. https://doi.org/10.1155/2018/9589208

10. Barakat, A., Meddah, R., Afdali, M., \& Touhami, F Physicochemical and microbial assessment of spring water quality for drinking supply in Piedmont of béni-mellal atlas (Morocco). Physics and Chemistry of the Earth, Parts A/B/C, 2018, 104, 3946. https://doi.org/10.1016/j.pce.2018.01.006

11. Kumar N. S, Rao M. V. S, Krishna M. P. S. M. Study of Some Physical \& Chemical Characteristic Properties of Groundwater in the Villages of Veeraghattam and Palakonda Mandals in Srikakulam District, A.P, India. Curr World Environ, 2015, Vol.10 (2) pp.610-618.

12. Ofodile, M.E. Groundwater study and development in Nigeria. University of Ibadan Press, Nigeria, 2002.

13. McCasland, M., N.M. Trautmann, R.J. Robert and K.S. Porter, Nitrate: Health effects in drinking water. 2007.

14. Varol, S., \& Davraz, A. Evaluation of the groundwater quality with WQI (Water quality index) and multivariate analysis: A case 
study of the Tefenni plain (Burdur/Turkey). Environmental Earth Sciences, 2014, 73(4), 1725-1744. https://doi.org/10.1007/s12665014-3531-z

15. Adimalla, N., \& Venkatayogi, S. Geochemical characterization and evaluation of groundwater suitability for domestic and agricultural utility in semi-arid region of Basara, Telangana state, South India. Applied Water Science, 2018, 8(1). https://doi.org/10.1007/s13201-018-0682-1

16. WHO, Guidelines for drinking water quality. World Health Organization, Geneva, 2012.

17. Nadikatla, S. K., Mushini, V. S., \& Mudumba, P. S. Water quality index method in assessing groundwater quality of Palakonda mandal in Srikakulam district, Andhra Pradesh, India. Applied Water Science, 2019, 10(1). https://doi.org/10.1007/s13201-0191110-X

18. Neisi, A., Mirzabeygi (Radfard), M., Zeyduni, G., Hamzezadeh, A., Jalili, D., Abbasnia, A., Yousefi, M., \& Khodadadi, R. Data on fluoride concentration levels in cold and warm season in city area of Sistan and Baluchistan province, Iran. Data in Brief, 2018, 18, 713-718. https://doi.org/10.1016/j.dib.2018.03.060

19. Taiwo, A.M. "Source identification and apportionment of pollution sources to groundwater quality in major cities in Southwest, Nigeria." Geofizika, 2012, Vol. 29, pp. 157-174.

20. APHA (American Public Health Association), Standard method for examination of water and wastewater, NW, DC 20036, 2012.

21. Singh, S., \& Hussian, A. Water quality index development for groundwater quality assessment of greater Noida sub-basin, Uttar Pradesh, India. Cogent Engineering, 2016, 3(1). https://doi.org/10.1080/23311916.2016.1177155

22. BIS, drinking water specifications. Bureau of Indian Standards, IS 10500, 2012.

23. Harilal, C. C., Hashim, A., Arun, P. R., and Baji, S. Hydrogeochemistry of two rivers of Kerala with special reference to drinking water quality. Ecology, Environment and Conservation, 2004, Vol. 10, no. 2, pp. 187-192.

24. Lalitha S, Kalaivani D, Selvameena R, Barani A.V. Assay on quality of water samples from medical college area in Thanjavur, India. Indian J Environ Protect, 2004, 24(12), 925-930.

25. Howladar, M. F., Al Numanbakth, M. A., \& Faruque, M. O. An application of water quality index (WQI) and multivariate statistics to evaluate the water quality around Maddhapara granite mining industrial area, Dinajpur, Bangladesh. Environmental Systems Research, 2017, 6(1). https://doi.org/10.1186/s40068-017-0090-9

26. Kumar, S. K., $\quad$ Rammohan, V., Sahayam, J. D., \& Jeevanandam, M. Assessment of groundwater quality and hydrogeochemistry of Manimuktha river basin, Tamil Nadu, India. Environmental Monitoring and Assessment, 2008, 159(1-4), 341351. https://doi.org/10.1007/s10661-008-0633-7

27. Narsimha, A., \& Rajitha, S. Spatial distribution and seasonal variation in fluoride enrichment in groundwater and its associated human health risk assessment in Telangana state, South India. Human and Ecological Risk Assessment: An International Journal, 2018, 24(8), 2119-2132. https://doi.org/10.1080/10807039.2018.1438176

28. Kuppuraj, R. M., Selvaraj, D., Govindaraj, S., Rangaswamy, M., Narayanasamy, J. R., \& Kuppanagounder, K. Assessment of groundwater quality in the flood plains of upper Palar river, India. Chinese Journal of Geochemistry, 2012, 31(1), 15-23. https://doi.org/10.1007/s11631-012-0544-8

29. Kundu, A., \& Nag, S. K. (2018). Assessment of groundwater quality in Kashipur block, Purulia district, West Bengal. Applied Water Science, 2018, 8(1). https://doi.org/10.1007/s13201-0180675-0

30. Ramakrishna, Ch., Mallikarjunarao, D., Subba Rao, K., and Srinivas, N. "Studies on Groundwater Quality in Slums of Visakhapatnam, Andhra Pradesh." Asian Journal of Chemistry. 2009, Vol. 21, pp. 4246-4250.

31. Brown, R. M., McClelland, N. I., Deininger, R. A., \& O'Connor, M. F. A water quality index - Crashing the psychological barrier. Indicators of Environmental Quality, 1972, 173-182. https://doi.org/10.1007/978-1-4684-2856-8_15

32. Khan, A., \& Qureshi, F. R. Groundwater quality assessment through water quality index (WQI) in new Karachi town, Karachi,
Pakistan. Asian Journal of Water, Environment and Pollution, 2018, 15(1), 41-46. https://doi.org/10.3233/ajw-180004

33. Tiwari, A. K. Singh, A. K., Singh, A. K., \& Singh, M. P. Hydrogeochemical analysis and evaluation of surface water quality of Pratapgarh district, Uttar Pradesh, India. Applied Water Science, 2015, 7(4), 1609-1623. https://doi.org/10.1007/s13201015-0313-Z

34. Sojobi, A. O. Evaluation of groundwater quality in a rural community in north central of Nigeria. Environmental Monitoring and Assessment, 2016, 188(3). https://doi.org/10.1007/s10661016-5149-y 